\title{
Enterpreneurial Talent and Intention Among Undergraduate Students: Case Study at English Language Education Department
}

\author{
Amri Tanduklangi ${ }^{*}$, Muhammad Khusnun Muhsin', Carlina Amri \\ 1 Universitas Halu Oleu, Indonesia \\ ¿Universitas Sulawesi Tenggara, Indonesia
}

Corresponding Author: Amri Tanduklangi, @amri.tanduklangi@gmail.com ABSTRACT

Entrepreneurship plays an important role in generating new wealth in an economy. The growth of entrepreneurial activities will produce innovation, create new jobs for the society, trigger economic growth, and reduce unemployment rates. Eentrepreneurship is a topic requiring a lot of attentions from academicians and researchers, especially the unemployment problem arising among undergraduate students. Therefore, the aim of this article was to have a good understanding on entrepreneurial talent and intention of undergraduate university students. The antecedent factor would be measuring students' risk taking, persuading, ambition, performer, leadership, and business management skill behavior. The subjects of the study were undergraduate students

ARTICLE INFO

Article history:

Received

June 13, 2020

Revised

July 09, 2020

Accepted

July 18, 2020
How to cite

Journal Homepage Published by who are majoring in English at the language education department and have attended five days workshop on economic literacy program conducted by Global Economic Awareness Project (GEAP) in 2019 academic year. This research study used quantative method and a research designed survey was administered to gather questions with answers associated with a 5 point Likert scale ranging from strongly agree to strongly disagree. The questionnaires of the research used Fishbein and Ajzen's Planned Behavior (TPB) theory, Shaver and Scott's personal traits, and Bandura's Self efficacy theory. The findings of the research reveal that 'risk taking' and 'ambition' factor had favorable results after students have attended short entrepreneurial course. Whereas, students' still says "neutral" on 'persuader', 'ambitious', 'performer', 'leadership', and 'business management factor'. It is safe to assume that students' still had fair intention in developing their entrepreneurial interest because they have little to no experience on entreprenurial field in hand. Explicit real-life entrepreneurship related activities were recommended for future workshop to upgrade the student's entrepreneurship talent and intention.

Keywords: Entrepreneurship Talent and Intention, Global Economic Awareness, Economic Literacy Program

Tanduklangi, A., Muhsin, M., \& Amri, C. (2020). Enerpreneurial Talent and Intention Among Undergraduate Students: Case Study at English Language Education Department. IJoASER (International Journal on Advanced Science, Education, and Religion), 3(2). 46-56.

https://doi.org/10.33648/ijoaser.v3i2.52

https://ojs.staialfurqan.ac.id/IJoASER/

STAI Al-Furqan Makassar 


\section{INTRODUCTION}

Entrepreneurship has become a trend throughout the world. It generates a nation economic growth and development. Dickson \& Nafukho stated that entrepreneurship is vital in creating and fulfilling a healthy economy (Dickson et al., 2018; Nafukho., 2008). As it is widely known that entrepreneurship is something to do with innovation that is innitiated and/or executed by an entrepreneur (Raja, Aris, Musa, 2020). Entrepreneur as someone who creates a new business in the face of risk and uncertainty with the goal of making profit and growth through the identifying of opportunities, assembling the necessary resources to take advantage and exploiting the identified opportunities (Scarborough, 2012). His described that Entrepreneurial profile includes attributes of desire for responsibility, preference for moderate risk, confidence in personal success, desire for immediate feedback, possesses high level of energy and a future orientation, skill in organization and that to an entrepreneur, money is a great way to keep score, but it is not as important as achievement. Literature reviews revealed that more research works are needed in examining the determinants of entrepreneurship intentions of students . Entrepreneurial motivation is not the same as "uniquely entrepreneurial personality traits". They disclosed that entrepreneurial motivation is a crucial topic in entrepreneur study and that more study is needed (Karini, 2010; Souitaris, 2007; Carsru \& Brannback, 2011). It is a much neglected area because in the past, most researchers assumed it was possible and sufficient in defining an entrepreneur by identifying the unique personality traits (Carsrud et al., 2011; Carsrud et al., 2017). Inclination towards entrepreneurship is commonly associated with several personal characteristics (values and attitudes, personal goals, creativity, risk-taking propensity and locus of control) that might be expected to be influenced by a formal program of education. It is believed that education also serves as a preparatory function in relation to new venture creation, transferring of knowledge and the relevant skills that increase the self-efficacy (Badura, 2015; Gorman et al., 2013) and effectiveness of the potential entrepreneur. There is also preliminary evidence that entrepreneurial attributes can be positively influenced by educational programs and that many entrepreneurship programs and courses are able to build awareness of entrepreneurship as a career option and to encourage favorable attitudes toward entrepreneurship.

For the unemployment issues among graduates, serious concern has been raised by policy makers and academicians. In curbing the issue, these graduates can choose to be self-employed. Many fresh graduates do possess the knowledge and skill that are important for starting-up own business, however, only a tiny percentage of students choose to be self-employed immediately after graduating, most of them prefer job hunting (Branchet et al., 2011; Ajzen, 2011; Krueger, 2000). Other researcher reported that may be due tothe lack of self-confidence or lack of encouragement or reassurance (Lim et al., 2012). There may also be others who are potential entrepreneurs but are not properly aware of the career options that are open to them. As becoming entrepreneur can be one of the options; their intention on becoming selfemployed had prompted researchers to investigate particularly on the influence of entrepreneurial characteristics and entrepreneurial intention among undergraduates towards entrepreneurial activities. Therefore, other researchers tried to select a sample that allows to make a differentiated analysis, by type of education (non-entrepreneurial students'), and to identify the relevant determinants in expressing the entrepreneurial intentions. In other words, it tried to see how much the entrepreneurial intentions are influenced by certain psycho-behavioral traits of the individual. Personality traits have 
proven to be the predictors of many aspects of entrepreneurship (Barringer et al., 2015; Shaver et al., 2010). Several antecedents' for personality traits include; Risk-taking propensity refers to individual's orientation of making decision in uncertain contexts (Nishantha et al., 2009) and any decision made by an individual or group risk takers which is in high level of uncertainty (Yandra, 2020). While, the aim of this research is to have a good understanding on entrepreneurial talent and intention of undergraduate's university students of English Language Education, Halu Oleo University of Indonesia. The antecedent factor will be measuring students' risk taking, persuading, ambition, performer, leadership, business management skill behavior. There is a belief that entrepreneurial education develops students' ability to approach business situations and to identify new opportunities.

\section{METHODS}

The population number of this study is 124 undergraduate students who have been studying in English Language Education Department at University Halu Oleo during 2019 academic year. 40 students' were collected for data analysis. It is purposive samplings of the university students of Faculty of Teacher Training and Education. The samples were collected from the students who join the short entrepreneurial course which consist of a-5 days meetings of economic literacy program which was conducted by a US based international nonprofit the Global Awareness Project (GEAP) in Halu Oleo University from May 13 - 17, 2019. The antecedent factor will be measuring students' behavior and intention on risk taking, persuading, ambition, performer, leadership, and business management skill factors. The questionnaire was made based on the Theory of Planned Behavior (TPB) by (Ajzen, 2011), personal traits by (Shaver, 2010), Self efficacy (Bandura, 1986; Beauchamp et al., 2019) and other additional factors.

This study is a descriptive quantitative analysis, using descriptive statistics tool to measure the central tendency with mean and the dispersion with standard deviation (S.D) of Lickerts's five scale questionnaire, by using a rating guide as follows: 4.01- 5=Strongly Agree, 3.71-4.00=Agree, 2.71-3.70=Neutral, 1.712.70=Disagree, 1-1.7=Strongly Disagree. Finally, the data collected were analyzed and grouped in terms of six antecedent factors; Risk-Taking, Persuading, Ambition, Performer, Leadership, and Business Management Skill.

\section{RESULT AND DISCUSSION}

The study findings were presented under the following sections:

\section{Risk taking factor on undergraduate students' entrepreneurial intention.}

Table 1: Mean and Standard Deviation ratings of Responses on Risk Taking Factor

\begin{tabular}{lllll}
\hline Risk Taking Factor on Undergraduate Students & Mean & S.D & Level \\
\hline $\begin{array}{l}\text { RT1. I like to do different ways of developing a } \\
\text { business }\end{array}$ & & 0.25 & $\begin{array}{l}\text { Strongly } \\
\text { Agree }\end{array}$ \\
$\begin{array}{l}\text { RT2: I like to create new innovations in } 4.25 \\
\text { increasing production }\end{array}$ & 0.59 & $\begin{array}{l}\text { Strongly } \\
\text { Agree }\end{array}$ \\
\hline
\end{tabular}




\begin{tabular}{llll}
\hline RT3: I like trying new businesses & 3.91 & 0.49 & Agree \\
RT4: I aspire to become a broker & 3 & 0.40 & Neutral \\
$\begin{array}{l}\text { RT5: I am afraid of facing failure } \\
\text { RT6: I like making business estimates }\end{array}$ & 3.91 & 0.64 & Agree \\
RT7: I can develop new ideas in & 3.83 & 0.68 & Agree \\
$\begin{array}{l}\text { entrepreneurship } \\
\text { RT8: I have an adventurous spirit }\end{array}$ & 3.91 & 1 & Agree \\
Total Average & 3.86 & 0.63 & Agree \\
\hline
\end{tabular}

Note: 4.01- 5=Strongly Agree, 3.71-4.00=Agree, 2.71-3.70=Neutral, 1.71-2.70=Disagree, $1-1.7=$ Strongly Disagree

Table 1 reveals that, the student entrepreneurial intention for risk taking factor mostly falls under "agree" category. This indicates that the students mostly agree to do different ways of developing business and creating innovation on production. The study also shows that the respondents are brave enough to take risk by facing failure and making estimates. Among all the options, the lowest students' result is on (RT4) with a mean value 3 . This indicates most respondents had low to no intention to become a broker or middle-man in business. Apart from this, the average standard deviation shows S.D $<1$, meaning the result of respondents feedback on risk taking factor is to be considered as low-variance or homogenous.

\section{Persuading factor on undergraduate students' entrepreneurial intention.}

Table 2: Mean and Standard Deviation ratings of responses on Persuading Factor

\begin{tabular}{|c|c|c|c|}
\hline Persuader Factor on Undergraduate Students & Mean & S.D & Level \\
\hline $\begin{array}{l}\text { Psua1: I am good at influencing other people to } \\
\text { do something }\end{array}$ & 3.75 & 0.92 & Agree \\
\hline Psua2: I am a good salesperson & 3.25 & 1.1 & Neutral \\
\hline Psua3: I can promote ideas or products well & 3.75 & 1.1 & Agree \\
\hline $\begin{array}{l}\text { Psua4: I am known to influence the policies of } \\
\text { leaders or leaders }\end{array}$ & 2.83 & 0.9 & Neutral \\
\hline Psua5: I tend to be shy in public & 3.33 & 0.74 & Neutral \\
\hline Psua6: I think other people will follow my advice & 3.5 & 0.76 & Neutral \\
\hline $\begin{array}{l}\text { Psua7: I can have ease conversation with } \\
\text { stubborn people }\end{array}$ & 3.4 & 0.9 & Neutral \\
\hline
\end{tabular}




\begin{tabular}{lccc}
\hline Psua8:I have good speaking skills in public & 3.5 & 0.64 & Neutral \\
Total Average & 3.42 & 0.90 & Neutral \\
\hline
\end{tabular}

Note: 4.01- 5=Strongly Agree, 3.71-4.00=Agree, 2.71-3.70=Neutral, 1.71-2.70=Disagree, 1-1.7=Strongly Disagree

The evidence from table 2 shows that student entrepreneurial intention for persuading factor mostly falls under "neutral" category. The data from the questionnaire as shown in Table 2 indicates that the students mostly had low skills in persuading people. By a high number standard deviation on most items it can be concluded that there are disparities on students answer regarding thequestions. Some students however have high level of confidence on persuading people but others don't. Persuading factor is something related to introvert and extrovert behavior. Among all the options, the lowest students' result is on (Psua4) with a mean value 2.83. The evidence shows that most students had low to no connection with leaders or politician cause they are still in college, therefore persuading factor still need to be re-assess in the future. Furthermore, Table 2 shows that the average standard deviation S.D $<1$, meaning the result of respondents feedback on persuading factor is to be considered also as low-variance or homogenous.

\section{Ambition factor on undergraduate students' entrepreneurial intention.}

Table 3: Mean and Standard Deviation ratings of responses on Ambition Factor

\begin{tabular}{|c|c|c|c|}
\hline $\begin{array}{l}\text { Need of achievement factor on Undergraduate } \\
\text { Students }\end{array}$ & Mean & S.D & Level \\
\hline $\begin{array}{l}\text { A1. I am not satisfied, until the target that I } \\
\text { planned can be achieved }\end{array}$ & 4 & 0.4 & Agree \\
\hline A2: I have a high morale on working & 3.9 & 0.64 & Agree \\
\hline $\begin{array}{l}\text { A3: to achieve the target, I often work beyond } \\
\text { working hours }\end{array}$ & 3.5 & 0.64 & Neutral \\
\hline A4: I like to plan targets to be achieved & 4 & 0.40 & Agree \\
\hline A5: I have high curiosity & 3.83 & 0.98 & Agree \\
\hline A6: I am sure of the results of my work & 3.25 & 0.82 & Neutral \\
\hline A7: I have a strong desire & 4 & 0.49 & Agree \\
\hline $\begin{array}{l}\text { A8: I always look for opportunities in } \\
\text { entrepreneurship }\end{array}$ & 3.5 & 0.5 & Neutral \\
\hline Total Average & 3.77 & 0.61 & Agree \\
\hline
\end{tabular}


Note: 4.01- 5=Strongly Agree, 3.71-4.00=Agree, 2.71-3.70=Neutral, 1.71-2.70=Disagree, 1-1.7=Strongly Disagree

Table 3 shows that the student entrepreneurial intention in terms of sense of achievement factor mostly falls under "agree" category, meaning the respondent had a fair ambition trait, not too ambitious but not low either. On several questions (A1, A4 \& A7), students agree that they are striving to achieve their target and have a strong desire to fulfill it. The data also shows if the respondent had high morale on working with good curiosity. Among all the options, the lowest students' result is on (A6) with a mean value 3.25, meaning most students is not sure if their work can meet the standard quality since they have never experienced with a startup business or real-job in hand. Along with this finding, the average standard deviation shows S.D $<1$, meaning the result of respondents feedback on ambition factor is again to be considered as low-variance or homogenous.

\section{Self-efficacy factor on undergraduate students' entrepreneurial intention.}

Table 4: Mean and Standard Deviation ratings of Responses on Self-Efficacy Factor

\begin{tabular}{|c|c|c|c|}
\hline Self-Efficacy factor of the Respondent & Mean & S.D & Level \\
\hline $\begin{array}{l}\text { Per1. I can attract the attention of people in the } \\
\text { surrounding environment }\end{array}$ & 3.66 & 0.62 & Neutral \\
\hline $\begin{array}{l}\text { Per2: I am not hesitated to show my strength in } \\
\text { front of people }\end{array}$ & 3.16 & 0.68 & Neutral \\
\hline Per3: I like being in a crowd & 3.58 & 0.75 & Neutral \\
\hline Per4: I can initiate an activity & 3.5 & 0.64 & Neutral \\
\hline Per5: I like to appear in public & 3.58 & 0.64 & Neutral \\
\hline $\begin{array}{l}\text { Per6: I am happy to be the center of attention of } \\
\text { others }\end{array}$ & 3.08 & 0.64 & Neutral \\
\hline $\begin{array}{l}\text { Per7: I feel less able to attract the attention of } \\
\text { others }\end{array}$ & 3.33 & 0.62 & Neutral \\
\hline Per8: I often feel less confident & 3.25 & 0.82 & Neutral \\
\hline Total Average & 3.39 & 0.68 & Neutral \\
\hline
\end{tabular}

Note: 4.01- 5=Strongly Agree, 3.71-4.00=Agree, 2.71-3.70=Neutral, 1.71-2.70=Disagree, 1-1.7=Strongly Disagree

Table 4 reveals that the students' entrepreneurial self-efficacy factor mostly fall under "neutral" category, meaning that the students mostly hesitate with their performance on entrepreneurial skill. This figure indicates that the students still have low self-efficacy. Among all the options, the lowest students' result is on (Per6) with a 
mean value 3.08. This shows mostly students' not in favor to be the center of attention. As seen from Table 4 the average standard deviation also shows S.D $<1$, meaning the result of respondent's feedback on self-efficacy factor as low-variance.

\section{Leadership factor on undergraduate students' entrepreneurial intention.}

Table 5: Mean and Standard Deviation ratings of Responses on Leadership Factor

\begin{tabular}{llll}
\hline Leadership factor of the respondent & Mean & S.D & Level \\
\hline $\begin{array}{l}\text { L1. I like being in charge of a group } \\
\text { L2: I can lead a group activity }\end{array}$ & 3.75 & 0.82 & Agree \\
$\begin{array}{l}\text { L3: I have a charismatic personality that is easy } \\
\text { to follow }\end{array}$ & 3.25 & 0.72 & Neutral \\
$\begin{array}{l}\text { L4: I know how to be a good and successful } \\
\text { leader }\end{array}$ & 3.41 & 0.75 & Neutral \\
$\begin{array}{l}\text { L5: I am often asked to provide guidance or } \\
\text { direction }\end{array}$ & 3.91 & 0.49 & Agree \\
$\begin{array}{l}\text { L6:I am known as a person who has a firm and } \\
\text { spontaneous attitude }\end{array}$ & 3.25 & 0.72 & Neutral \\
$\begin{array}{l}\text { L7:I dare take responsibility } \\
\text { L8:I aspire to be a leader/influential person }\end{array}$ & 3.5 & 0.95 & Neutral \\
\hline \begin{tabular}{l} 
Total Average \\
\hline
\end{tabular}
\end{tabular}

Note: 4.01- 5=Strongly Agree, 3.71-4.00=Agree, 2.71-3.70=Neutral, 1.71-2.70=Disagree, 1-1.7=Strongly Disagree

Table 5 indicates that the respondent s' personal leadership trait factor mostly fall under "neutral" category, meaning the students mostly had low skills in leadership. Although some students like being in charge of group and asked to provide guidance or direction but it's not enough to make the students' sure they had sufficient skill to be a skilled leader in entrepreneurship. Since most students' hesitate to give positive answer on leadership questions, we can assume that students' need to learn more about leadership in entrepreneurship in the future. Among all the options, the lowest students' result is on (L7) with a mean value 3.16, meaning most students' had low to no intention to take responsibility in entrepreneurial field and prefer to stay in comfort zone; the result slightly contradicts with their result on risk factor. Also, the average standard deviation shows S.D $<1$, meaning the result of respondents feedback on leadership factor is considered as homogenous.

Business Managementt Skill factor on undergraduate students' entrepreneurial intention. 
Table 6: Mean and Standard Deviation ratings of Responses on Business Managementt Skill Factor

\begin{tabular}{|c|c|c|c|}
\hline $\begin{array}{lcccc}\text { Business } & \text { Management } & \text { Skill } & \text { Factor } & \text { on } \\
\text { Undergraduate Students } & & & \\
\end{array}$ & Mean & S.D & Level \\
\hline BM1. I was able to arrange the budget well & 3.41 & 0.64 & Neutral \\
\hline $\begin{array}{l}\text { BM2: I have the dream of becoming a reliable } \\
\text { manager }\end{array}$ & 3.66 & 0.47 & Neutral \\
\hline $\begin{array}{l}\text { BM3: I can develop relationships or networks } \\
\text { widely }\end{array}$ & 3.41 & 0.86 & Neutral \\
\hline $\begin{array}{l}\text { BM4: I like to take courses/trainings on business } \\
\text { management }\end{array}$ & 3.91 & 0.49 & Agree \\
\hline
\end{tabular}

$\begin{aligned} & \text { BM5: I can implement the best service in } 3.5 \\ & \text { entrepreneurship }\end{aligned}$
$\begin{aligned} & \text { BM6: I am able to operate a business / business } \\ & \text { from afar (from home) }\end{aligned}$

BM7: I have an adequate experience in managing $3.41 \quad 0.86 \quad$ Neutral
business

BM8: I am a person who has good business $3.25 \quad 0.72 \quad$ Neutral management skills

$\begin{array}{llll}\text { Total Average } & 3.53 & 0.66 & \text { Neutral }\end{array}$

Note: 4.01- 5=Strongly Agree, 3.71-4.00=Agree, 2.71-3.70=Neutral, 1.71-2.70=Disagree, 1-1.7=Strongly Disagree

Evidence from table 6 reveals that the respondent business management skill mostly fall under "neutral" category. The data from the questionnaire responsesindicates that the students mostly had low skills in business management skill, even though they agree to take courses/training on business management to improve their business skill. In addition, the study shows that most respondents were unsure be able to arrange the budget plan and be able to operate business from distance. Meanwhile, the average standard deviation shows S.D $<1$. This indicates the respondents' feedback on business management skill factor is again to be considered as homogenous.

The finding showed that Risk Taking and Ambition factor had a favorable result after students' short entrepreneurial course through economic literacy program conducted by GEAP teamwork in cooperation with English Department of Halu Oleo University. Whereas, respondents were mostly dominant on "neutral" statement on persuading factor, sense of achievement, self-efficacy, leadership skill, and business management personal traits. It is safe to assume that students' still had fair intention in 
developing their entrepreneurial interest (Carsrud et al., 2017). Only a handful of respondent sees an opportunity and an interest in entrepreneurship after they attended the course. The findings are insightful for the Global Awareness Project (GEAP) team work or related program instructor in designing and enhancing the entrepreneurship course structure (Ajzen, 2011), subjects offering as to be proactive enough and practical-oriented with the aim of sustaining students' interest in entrepreneurship .

\section{CONCLUSIONS}

This study had made an understanding on the personal traits which affect students' entrepreneurial intention. The results reveals that only Risk Taking and Ambition factor had a favorable result after students attended short entrepreneurial course through economic literacy program conducted by GEAP teamwork in cooperation with English Department of Halu Oleo university. Whereas, respondents were mostly dominant on "neutral" statement on persuading factor, sense of achievement, self-efficacy, leadership skill, and business management personal traits. It is safe to assume that students' still had fair intention in developing their entrepreneurial interest. Only a handful of respondent sees an opportunity and an interest in entrepreneurship after they attended the course. The findings are insightful for the GEAP team work or related program instructor in designing and enhancing the entrepreneurship course structure, subjects offering as to be proactive enough and practical-oriented with the aim of sustaining students' interest in entrepreneurship. In addition, it is advisable for the teamwork organize more entrepreneurial-related activities or programs and workshops in the future that can develop students'entrepreneurial culture, for instance, nurturing some entrepreneurial skills through project based activities like making business plan proposal, working with real-life business, such as managing or running small business on campus or during flea markets, providing opportunities for students to involve in managing their own business and involve them in attachment business management programs. Short course of entrepreneurial which is only a part of the whole short course curriculum under the umbrella of Economic Literacy Program may not sufficient enough to upgrade students' intention on entrepreneuship as they are still lacking of experiencing the real business in hand.

\section{ACKNOWLEDGEMENTS}

Thank you for the Institute for Research and Community Service (LPPM) University Halu Oleo who gave permission to conduct this research. Thanks also go to the students of English Education Study Program for participating in this research. Thank also giving for our friends to give contribution in helping to collect data

\section{AUTHOR CONTRIBUTION STATEMENTS}

Amri Tanduklangi (AR) was the main author in this article. Muhammad Khusnun Muhsin (MKM) was the second author who provided support of this research. This study was designed by researchers with background of classroom problems. Carlina Amri (CA) was the third author. This research was a collaborative research of two universities. In this research, AR and MKM jointly design research, collect data, conduct analysis and conduct dissemination together. Then, CA is the third author as researcher who helps finishing this research. 


\section{REFERENCES}

Ajzen, I. (2011). The theory of planned behaviour: Reactions and reflections. https:// doi.org/10.1080/08870446.2011.613995

Bandura, A., "Social Foundations of Thought and Action: A Social Cognitive Theory". Prentice Hall, Englewood Cliffs, NJ., USA., ISBN-13: 978-0138156145, (1986), pp. 617. Google Scholar

Beauchamp, M. R., Crawford, K. L., \& Jackson, B. (2019). Social cognitive theory and physical activity: Mechanisms of behavior change, critique, and legacy. Psychology of Sport and Exercise, 42, 110-117. https:// doi.org/10.1016/j.psychsport.2018.11.009

Barringer, B. R. (2015). Entrepreneurship: Successfully launching new ventures. Pearson Education India. Google Scholar

Branchet B., Augier, B., Boissin J.P., and Quere, B. "Strategic governmental economic activities in support of young French SMEs", Journal of Small Business and Enterprise Development, Vol. 18 (2), (2011), pp. 384 - 402. https:/ / doi.org/10.1108/14626001111127133

Carsrud, A. and Brännback, M., "Entrepreneurial motivations: What Do We Still Need to Know?" Journal of Small Business Management, Vol. 49(1), (2011), pp. 926.sbm_312 9. Google Scholar

Carsrud, A., Brännback, M., Elfving, J., \& Brandt, K. (2017). Motivations: The entrepreneurial mind and behavior. In Revisiting the Entrepreneurial Mind (pp. 185209). Springer, Cham. https:/ / doi.org/10.1007/978-3-319-45544-0_13

Gorman, G., Hanlon, D. \& King, W., "Some research perspectives on entrepreneurship education, enterprise education and education for small business management: A Ten-Year Literature Review", International Small Business Journal, 15(3), (1997), pp. 56-77. https:/ / doi.org/10.1177\%2F0266242697153004

Hyder, A., Azhar, A., Javaid, A., \& Rehman, M. (2011). Entrepreneurial intentions among business students in Pakistan. Journal of Business Systems, Governance and Ethics, 5(2).. Google Scholar

Karimi, S., Chizari, M., Biemans, H.J.A. and Mulder, M., "Entrepreneurship education in Iranian higher education: The Current State and Challenges", European Journal of Scientific Research, Vol. 48(1), (2010), pp. 35-50. Google Scholar

Krueger Jr, N. F., Reilly, M. D., \& Carsrud, A. L. (2000). Competing models of entrepreneurial intentions. Journal of business venturing, 15(5-6), 411-432. https:/ / doi.org/10.1016/S0883-9026(98)00033-0

Hong-Da, L., Vivian, C. C. H., Chin-Tien, H., \& Wu-Chen, F. (2014). Relationship between Entrepreneurial Leadership and Innovative Behavior: The Mediating Effect of Entrepreneurial Self-Efficacy and the Moderating Effect of Openness to Experience and Extraversion. Information Technology Journal, 13(6), 1035. Google Scholar

Ma, J. and J. Tan, "Key components and implications of entrepreneurship: A 4-P framework". J. Bus. Venturing, (2006), 21, pp. 704-725. https:// doi.org/10.1016/j.jbusvent.2005.04.009

Nafukho, F., Nafukho, F. M., \& Muyia, M. A. H. (2010). Entrepreneurship and socioeconomic development in Africa: a reality or myth?. Journal of European Industrial Training. https:// doi.org/10.1108/03090591011023961

Nishantha, B. (2009). Influence of personality traits and socio-demographic background of undergraduate students on motivation for entrepreneurial career: The Case of Sri Lanka. Google Scholar 
Lee, W. N., Lim, B. P., Lim, L. Y., Ng, H. S., \& Wong, J. L. (2012). Entrepreneurial intention: A study among students of higher learning institution (Doctoral dissertation, UTAR). Google Scholar

Raja, N., Aris, A., and Musa, H., "The Effect of Interapreneurial Competencies on Innovative Work Behavior : A Case of Cyber Security Experts in Malaysia", International Journal of Advanced Science and Technology, 29(6), (2020), pp. 351365. Google Scholar

Shaver, K. G., \& Scott, L. R. (1992). Person, process, choice: The psychology of new venture creation. Entrepreneurship theory and practice, 16(2), 23-46. https:// doi.org/10.1177\%2F104225879201600204

Scarborough, N. M., "Effective small business management: An entrepreneurial approach", 10th Edition, NewJersey: Prentice Hall, (2012), HD62.7.S27. Google Scholar

Souitaris, V., Zerbinati, S., \& Al-Laham, A. (2007). Do entrepreneurship programmes raise entrepreneurial intention of science and engineering students? The effect of learning, inspiration and resources. Journal of Business venturing, 22(4), 566-591. https:/ / doi.org/10.1016/j.jbusvent.2006.05.002

Yandra, F.P., Sopacua, I.O., "Chances in Risk-Taking of Financial System Subjects (Household) in the Digital Era". International Journal of Advance Science and Technology, 29(105), (2020), pp. 45-52. Google Scholar 